Anna Rygorowicz-Kuźma

Uniwersytet w Białymstoku

Wydział Filologiczny

Instytut Filologii Wschodniosłowiańskiej

tel. +48 857457450

e-mail: anna.rygorowicz-kuzma@uwb.edu.pl

\title{
Великдень сzy Wielkanoc? \\ O słowiańskich nazwach święta Zmartwychwstania Pańskiego
}

Słowa kluczowe: leksyka religijna, święta chrześcijańskie, język rosyjski, język polski

Zmartwychwstanie Pańskie to bardzo ważne wydarzenie dla świata chrześcijańskiego. Przedstawione jest ono w Biblii, w każdej z czterech Ewangelii Nowego Testamentu. Ewangeliści opisują ostatnie dni ziemskiego życia Jezusa Chrystusa, m.in. Jego przybycie do Jerozolimy na święto Paschy, Ostatnią Wieczerzę z uczniami, pojmanie, sąd, cierpienia i śmierć na krzyżu oraz złożenie do grobu. Sam akt Zmartwychwstania pozostaje w Ewangeliach tajemnica, wszystkie notują natomiast informacje o pustym grobie. Ewangelista Marek opisuje to wydarzenie następująco: „Po upływie szabatu Maria Magdalena, Maria, Matka Jakuba, i Salome nakupiły wonności, żeby pójść namaścić Jezusa. Wczesnym rankiem w pierwszy dzień tygodnia przyszły do grobu, gdy słońce wzeszło. A mówiły między sobą: «Kto nam odsunie kamień od wejścia do grobu?» Gdy jednak spojrzały, zauważyły, że kamień był już odsunięty, a był bardzo duży. Weszły więc do grobu i ujrzały młodzieńca, siedzącego po prawej stronie, ubranego w białą szatę; i bardzo się przestraszyły. Lecz on rzekł do nich: «Nie bójcie się! Szukacie Jezusa z Nazaretu, ukrzyżowanego; powstał, nie ma Go tu. Oto miejsce, gdzie Go złożyli. Lecz idźcie, powiedzcie Jego uczniom i Piotrowi: Idzie przed wami do Galilei, tam Go ujrzycie, jak wam powiedział». One wyszły i uciekły od grobu: ogarnęło je bowiem zdumienie i przestrach. Nikomu też 
nic nie oznajmiły, bo się bały" (Mk 16, 1-8)1. Do czasu wniebowstąpienia Zmartwychwstały Chrystus wielokrotnie ukazywał się i rozmawiał ze swoim uczniami². Wymowne są słowa Chrystusa, skierowane do apostoła Tomasza, który uwierzył w zmartwychwstanie Pana dopiero wtedy, gdy dotknął Jego ran: „Uwierzyłeś dlatego, ponieważ Mnie ujrzałeś? Błogosławieni, którzy nie widzieli, a uwierzyli" (J 24, 29).

Misterium śmierci i zmartwychwstania Jezusa Chrystusa stanowi istotę wiary chrześcijańskiej, jest jej fundamentem i drogowskazem. Akt zmartwychwstania potwierdza Jego Boskość i jest ,śmierci uśmierceniem, zburzeniem piekła, innego, przyszłego życia początkiem" [za: Bondaruk 1987, 99]. Ostatnia Wieczerza, którą Chrystus spożył z uczniami staje się zaczątkiem spotkania z Nim w Eucharystii, dzień Zmartwychwstania Chrystusa - cotygodniowym Dniem Pańskim. Nie dziwi fakt, iż święto upamiętniające tajemnicę Zmartwychwstania Pańskiego jest najstarszym i najważniejszym świętem w kalendarzu świąt chrześcijańskich. Jest to święto ruchome, obchodzone w pierwszą niedzielę po pierwszej wiosennej pełni księżyca. W związku z tym, iż zmartwychwstanie Chrystusa nastąpiło zaraz po żydowskim święcie Pesach (aram. Pascha), ta biblijna nazwa w wielu językach przeniesiona została również na święto chrześcijańskie, por. np. fr. Pâques, włos. $P a$ squa, hiszp. Pascua, szwed. Påsk, nowogr. $\pi a ́ \sigma \chi a$, ros. Пacxa itp. Przypomnieć należy, że hebr. pesach, aram. pascha oznacza 'przejście', 'ominię-

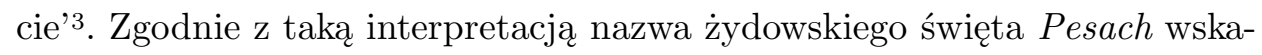
zuje bezpośrednio na wydarzenie biblijne, opisane w Starym Testamencie, dotyczące ominięcia przez Boga domów Izraelitów, oznaczonych krwią baranka, podczas ostatniej plagi egipskiej. W szerszym rozumieniu Pesach to także przejście narodu wybranego z ziemi egipskiej przez Morze Czerwone do Ziemi Obiecanej. Chrześcijańska interpretacja Paschy również nawiązuje do obietnicy wyzwolenia ludzkości poprzez jej przejście od śmierci do życia wiecznego, którego gwarantem jest Zmartwychwstały Chrystus. Nazwa Pascha jest więc umotywowana teologicznie. W językach słowiańskich święto Zmartwychwstania Pańskiego otrzymuje jednak najczęściej nazwy rodzime, zob. np. pol. Wielkanoc, czesk. Vielikonoce, ukr. (też ros. lud.) Великдень, białorus. Вялікдзень, bułg. Великден, sch. Ùskrs. Ze względu na obszerność tego tematu poniższe rozważania nie obejmą wszystkich słowiańskich nazw

\footnotetext{
1 Wszystkie cytaty z Pisma Świętego przytoczone są za tzw. Biblią Tysiąclecia [zob. Pismo Święte Starego i Nowego Testamentu, 1980].

2 Zob. np. cyt.: „ukazywał się im [apostołom] przez 40 dni i mówił o królestwie Bożym” (Dz 1, 3); zob. też: J 20, 19-22; J 21, 1-19; Łk 24, 36-49; Mk 16, 14-17.

3 Zob. np. WSWO [2010, 948].
} 
chrześcijańskiego święta Paschy. Zostaną one ograniczone przede wszystkim do zagadnienia genezy i historii rosyjskiego złożenia Великдень i polskiego Wielkanoc. Nazwy te mają podobną strukturę i wspólny człon wielki. Interesujący jest też fakt, dlaczego w języku rosyjskim (oraz pozostałych językach wschodnio- i po części południowosłowiańskich) Zmartwychwstanie to 'wielki dzień', a w języku polskim (i innych zachodniosłowiańskich) zaś 'wielka noc'.

\section{Nazwa Великдень}

Wschodniosłowiański zrost Великдень został utworzony najprawdopo-

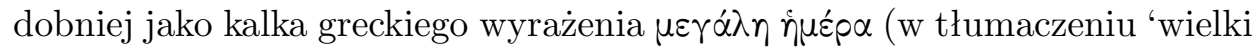
dzień") ${ }^{4}$. Nazwę tę rejestruje już Ewangeliarz Ostromira ${ }^{5}$, obok częściowo synonimicznego jej zapożyczenia nасха ${ }^{6}$. Złożenie великъ дьнь było tam przede wszystkim określeniem święta Zmartwychwstania Pańskiego, ale mogło też występować w znaczeniu szerszym 'święto'7. W najstarszych słowiańskich zabytkach rękopiśmiennych z X i XI w. nazwa великъ дьнь (również $\mathrm{w}$ formie велии дьнь) poświadczona była zarówno $\mathrm{w}$ znaczeniu ogólnym 'święto', jak też w znaczeniu węższym 'święto Paschy's. Należy tu wspomnieć, iż nazwa Пacxa odnosiła się nie tylko do święta chrześcijańskiego, ale i przede wszystkim żydowskiego ${ }^{9}$. Великдень był więc określeniem zarówno Paschy żydowskiej, jak i Wielkanocy. W źródłach leksykograficznych języka rosyjskiego XI-XVII w. nazwa Великдень poświadczona jest w zapisach Велик день, Велик-день, Великдень, Великодень ${ }^{10}$. Jak podaje M. Vasmer, kompozycja ta funkcjonowała w języku rosyjskim do XVI w.

\footnotetext{
4 Zob. np.: Fas. [I, 288], Srez. [I, 236].

5 Zob.: Fas. [I, 288], Srez. [I, 236].

6 W Ewangeliarzu Ostromira leksem nacxa poświadczony jest w znaczeniach: 1. „иудейский праздник в память избавления Евреев от египетского рабства” 2. „хлеб пасхальный у Иудеев” 3. „христианский праздник пасхи, день Воскресения Христова” [Srez. II, 566].

7 Zob. Srez. [I, 236].

8 Zob. SS [1994, 202].

9 Zob. SS [1994, 443], Srez. [II, 566]. Por. tė̇ SRJ: nacxa - 1. „весенний религиозный праздник у евреев в память избавления от египетского рабства” 2. „пасхальная трапеза у евреев - жертвенный агнец с горькими травами и пресный хлеб” 3. „пасхальный (жертвенный) агнец” 4. „христианский праздник пасхи (в память воскресения Христа)” 5. „обрядовое кушанье изготовляемое по православному обычаю ко дню пасхи и освящаемое в церкви” 6. „страстная неделя” [XIV, 168-9].
}

10 Zob. np. SRJ [II, 63-64]. 
[Fas. I, 288]. Słowniki XVIII i XIX wieku formę tę traktują już jako „dawną”, „archaiczną” bądź „ludową”, por. nр.: Велик день, Велик-день - „в старину называли так Светлое Христово Воскресенье; да и ныне, если не ошибаюсь, сохранилось сие название в некоторых областях России" [SRJ III, 12-16], Велик день - „стар. День Св. Пасхи; светлое воскресенье" [SAN I, 108] ${ }^{11}$.

Równolegle z określeniem Велик день w języku rosyjskim od jego zarania funkcjonowała nazwa Пacxa. Z czasem zaczęła ona stopniowo wypierać formę słowiańską. Być może było to związane z faktem, iż nazwa Великдень nie oddawała całej wagi święta Zmartwychwstania Pańskiego, tym bardziej, że mogła występować też w znaczeniu szerszym, bardziej ogólnym, określając każde 'święto'. Właśnie to znaczenie jako pierwsze podaje ks. G. Djaczenko w swoim dziele Полный церковно-славянский словарь, zob.: Велик день - 1. „праздник” 2. „светлое Христово воскресение” 3. „еврейская пасха” [Djacz., 916]. W chrześcijaństwie wschodnim święto Paschy traktowane jest jako centralne, najważniejsze święto w kalendarzu liturgicznym. Nie jest włączane do tzw. dwunastu wielkich świąt (cs. двyнадесятые праздники), gdyż w świątecznej hierarchii znajduje się ponad nimi. Status święta Zmartwychwstania Pańskiego odzwierciedlają określenia zawarte w kanonie paschalnym: „święto świąt i uroczystość nad uroczystościami” («праздников праздник и торжество из торжеств») [Триодь иветная, 1992]. W księgach liturgicznych, zwłaszcza w Triodionie Kwiecistym poświęconym nabożeństwom paschalnym nazywane jest ono Cвятая и Великая Неделя Пасхи ${ }^{12}$. W wyrażeniu tym występują oba człony analizowanej tu nazwy Великдень w postaci Великая Неделя ${ }^{13}$, ale dopełnia ją jeszcze przymiotnik Святая i rzeczownik Пасха. Termin Пасха jest obecny w oficjalnej nazwie święta Zmartwychwstania Pańskiego notowanej w kalendarzu cerkiewnym: Светлое Христово Воскресение. Пасха. Wydaje się, iż nawet złożenie Воскресение Христово nie jest tak powszechne we współczesnym języku rosyjskim jak zapożyczenie Пacxa. Nazwa ta jest najbliższa istocie święta, gdyż wskazuje na ścisły związek śmierci i zmartwychwstania Chrystusa z paschą żydowską ${ }^{14}$. Jest to nazwa starożyt-

11 Por. też DAL: Велик-день - „стар. и поныне южн. светлое Христово Воскресение” [I, 192].

12 Zob. nр. Триодь иветная [1992].

13 Należy tu dodać, iż cerkiewnosłowiańskie określenie неделя ma przede wszystkim znaczenie 'dzień', a okres tygodniowy to седмица, nр. светлая седмица (tj. Oktawa Paschalna, Tydzień Paschalny).

14 Na ten temat zob. np. IRS [131]. 
na, którą świat chrześcijański zapożyczył od Hebrajczyków, por. hebr. pe-

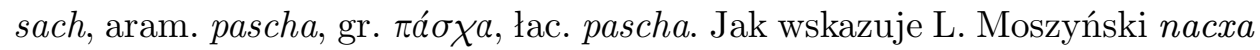
była też podstawową nazwą święta Zmartwychwstania Pańskiego w najstarszych staro-cerkiewno-słowiańskich zabytkach piśmienniczych, tj. tekstach ewangelicznych [Moszyński 1973, 108]15. Wydaje się, iż formy Великдень, Великодень oraz wyrażenia z utworzonymi od nich przymiotnikami великоденный, великоденский (nр. Великоденная неделя ${ }^{16}$ ) mogły też wchodzić w interferencję z innymi nazwami zawierającymi człon великиŭ, dotyczącymi na przykład dni Wielkiego Tygodnia, por. nazwy Великиŭ четверг, Великая пятнича, Великая суббота, Великая седмича itp. Obecność przymiotnika великиŭ w nazwie tygodnia (i dni tygodnia) przedpaschalnego ks. G. Djaczenko objaśnia następująco: „Великая седмица страстная, между неделями великого поста и святой Пасхи, названа так по совершившимся в нее великим таинствам искупления человеческого (...)" [Djacz., 69]. Trzeba tu wspomnieć, iż w terminologii cerkiewnej nazwy Wielkiego Tygodnia i jego kolejnych dni mogły zawierać przymiotnik великий, ale też страстной, który bezpośrednio wskazywał na cierpienia i męki, jakich musiał doznać Jezus Chrystus przed Zmartwychwstaniem. Stąd obecność w języku rosyjskim nazw Страстная неделя, Страстная седмича, Страстной вторник, Страстная пятнича itp. W Triodionie Postnym Wielki Tydzień określany jest jako Hedeлs cnaсительных страстей ${ }^{17}$.

Wracając do nazwy Великдень w języku rosyjskim zachowała się ona $\mathrm{w}$ tradycji ludowej. O obecności nazwy w języku świadczą porzekadła ludowe, np.: „Дорого яичко к велику дню”, „Дуй не дуй, а великдень у порога”, „Дуй не дуй, не к рождеству идет, к великодню”, „Шить ли (Мыть ли), белить ли, а завтра великдень”, „И дурак знает, что великдень праздник" 18 itp. W języku białoruskim i ukraińskim rodzime zrosty Вялікдзень ${ }^{19}$ (białorus.), Великдень ${ }^{20}$ (ukr.) funkcjonują do dnia dzisiejszego, choć równolegle używana jest też nazwa Пacxa $a^{21}$.

\footnotetext{
15 Oczywiście oprócz nazwy nacxa w słownikach języka starosłowiańskiego zarejestrowane są też inne określenia tego święta, por. np. formy велии дьнь [SS, 110], великъ дьнь [SS, 110; SSJ I, 173], нед қақ векікины пасха [SSJ I, 173].

16 Zob.: Великоденная неделя - „неделя, начинающаяся праздником пасхи” [SRJ II, 64].

17 Zob. Триодь постная [1992].

18 http://www.wisdoms.ru/poslovizi_i_pogovorki/ru/14_3.html [12.12.2016].

19 Zob. np. TSBM [137], por. też RBS [II, 452].

20 Zob. np. ESUM [I, 346], SUP [57].

21 Zob. np.: PBS [719], ESUM [IV, 313], SUP [309].
} 


\section{Nazwa Wielkanoc}

W języku polskim podstawowym określeniem święta Zmartwychwstania Pańskiego jest nazwa Wielkanoc. Występowała ona już w języku staropolskim w formach Wiel(i)ka Noc, Wiel(i)konoc, Wielikonoc [SStp. X, z. 3, 168 i 172]. Te słowiańskie złożenia były zapożyczeniami staroczeskimi²2 (por. stczes. Velika Noc, velikonoc, velkonoc), podobnie jak większość najdawniejszych polskich terminów chrześcijańskich. Nazwy Wiel(i)ka Noc, Wiel(i)konoc, Wielikonoc odnosiły się nie tylko do święta chrześcijańskiego, ale i żydowskiego, zob.: Wiel(i)ka Noc - „święto żydowskie obchodzone na pamiątkę wyjścia z Egiptu, Pascha, dies festi Iudaeorum" [SStp. t. X, z. 3, 168]. W języku staropolskim raczej nie używano jeszcze określenia Pascha ${ }^{23}$. W słowniku SStp. w znaczeniu 'Wielkanoc, Pascha' zarejestrowana jest też nazwa Wiela Niedziela [SStp. X, z. 3, 161]. Przymiotnik wiela (podstawowa forma: wieli, por. staroruskie велий) podobnie jak wielki określał m.in. rzeczy i wydarzenia 'mające duże znaczenie, ważne, uroczyste' [SStp. X, z. 2, 160]. Rzeczownik niedziela wskazywał na dzień tygodnia szczególny dla chrześcijan, choć mógł też oznaczać cały tydzień ${ }^{24}$. Wydaje się jednak, iż złożenie Wiela Niedziela dotyczyło przede wszystkim święta Zmartwychwstania Pańskiego. Było też częściowo zbieżne z cs. wyrażeniem Святая и Великая Неделя Пасхи, funkcjonującym w języku chrześcijaństwa wschodniego. Określenie Wielka Niedziela używane jest i współcześnie $^{25}$. O ile wyrażenie to odnajdujemy w niektórych źródłach, podstawową i najbardziej aktywną nazwą pozostaje forma Wielkanoc. Analizując tę nazwę nie sposób nie odnieść się do zagadnienia, związanego z genezą członu 'noc'. Dlaczego w odróżnieniu od języków wschodniosłowiańskich w nazwie tego święta zachowany został rdzeń noc? Problem etymologii nazwy Wielkanoc był już częściowo poruszany przez językoznawców, choć nie został jednoznacznie rozstrzygnięty ${ }^{26}$. Przypomnieć tu należy, iż nazwa została zapożyczona bezpośrednio z języka czeskiego, skąd na ziemie polskie dotarło chrześcijaństwo. Czy źródła czeskie wyjaśniają pochodzenie tej nazwy?

22 Zob. np. M. Basaj, J. Siatkowski [1978, 32].

23 SStp. nie odnotowuje jeszcze terminu Pascha, a jedynie formę paska (z notatką: wyraz niepewny) w znaczeniu 'wypiek wielkanocny' oraz przymiotnik paschowy w znaczeniu 'wielkanocny' [SStp. VI, z. 1, 42]. Na temat terminu Pascha w języku polskim zob. też A. Rygorowicz-Kuźma [2016, 341-342].

24 Zob. SStp. [V, z. 3, 177-178].

25 Zob. np. RE [IX, 410].

26 Zob. np.: Kwilecka [1996], Dubisz [2010]. 
V. Machek wskazuje, że forma ta mogła powstać pod wpływem innej nazwy, mianowicie nazwy święta Bożego Narodzenia vánoce [Machek 1957, 560]. Ta z kolei była zapożyczeniem staroniemieckim wînnahten i miała znaczenie 'święta noc'. Czy nazwa Bożego Narodzenia rzeczywiście została przeniesiona na święto Zmartwychwstania Pańskiego pozostaje jedynie przypuszczeniem, V. Machek z czasem porzuca tę myśl i próbuje dowodzić pochodzenia nazwy od nocnej pory celebracji święta [Kwilecka 1996, 192]. Wydaje się jednak, iż może istnieć związek między nazwami Vanoce i Vielika noc. W, „świętą noc" Jezus Chrystus rodzi się dla ludzkości, aby następnie poprzez swoją śmierć złożyć ofiarę za grzechy człowieka, w „wielką noc” pokonuje śmierć, by upadłemu człowiekowi dać życie wieczne.

Maria Karpluk, znawczyni staropolskiej terminologii religijnej, wskazuje, iż element -noc wzięty został z realiów starotestamentowego święta Paschy [Karpluk 2001, 280]. Rzeczywiście, to właśnie nocą rozegrały się wydarzenia, które zmusiły faraona do wypuszczenia hebrajczyków z Egiptu: „Tej nocy przejdę przez Egipt, zabije wszystko pierworodne w ziemi egipskiej od człowieka aż do bydła i odbędę sąd nad wszystkimi bogami Egiptu Ja, Pan. Krew będzie wam służyła do oznaczenia domów, w których będziecie przebywać. Gdy ujrzę krew, przejdę obok i nie będzie pośród was plagi niszczycielskiej, gdy będę karał ziemię egipską" (Wj 12, 12-13). Obrzędowość święta Paschy żydowskiej również koncentruje się na wieczorze i nocy. Wieczorem podczas tradycyjnego posiłku spożywa się pieczonego ofiarnego baranka z przaśnym chlebem i gorzkimi ziołami. Posiłek należy zakończyć do północy, tak jak podczas wyjścia Żydów z Egiptu.

Czy z porą nocną można też powiązać wydarzenia Nowego Testamentu, związane ze śmiercią i zmartwychwstaniem Jezusa Chrystusa? W Ewangeliach dość jednoznacznie została określona godzina śmierci Chrystusa: „Było już około godziny szóstej i mrok ogarnął całą ziemię aż do godziny dziewiątej. Słońce się zaćmiło i zasłona przybytku rozdarła się przez środek. Wtedy Jezus zawołał donośnym głosem: «Ojcze, w Twoje ręce powierzam ducha mojego». Po tych słowach wyzionął ducha" (Łk 23, 44-46). Podział na jednostki czasowe w okresie, gdy powstawały Ewangelie nie był tożsamy z dzisiejszym podziałem czasu, ale można jednoznacznie ustalić, iż przedział godzin szósta-dziewiąta odpowiadał współczesnym godzinom popołudniowym, mianowicie okresowi od godziny 12 do $15^{27}$. Śmierć Chrystusa dokonała się zatem w dzień, a mrok który wówczas zapadł związany był z zaćmieniem słońca. Ciało Chrystusa zdjęto z krzyża i złożono do grobu tego samego dnia wieczorem, gdyż następnego dnia następował szabat.

27 Zob. na ten temat EK [V, 1234, hasło: godzina]. 
Moment zmartwychwstania Chrystusa pozostaje dla nas tajemnicą, jednak na podstawie ksiąg Nowego Testamentu możemy określić porę dnia, w której to nastąpiło. Ewangelie informują nas o pustym grobie, który o świcie pierwszego dnia po szabacie zastają niewiasty niosące wonności, by namaścić ciało Chrystusa, por. np.: „Wczesnym rankiem w pierwszy dzień tygodnia przyszły do grobu, gdy słońce wzeszło" (Mk 16, 2). Ewangelia św. Jana wskazuje na okres, jeszcze przed wschodem słońca: „(...) wczesnym rankiem, gdy jeszcze było ciemno (...)" (J 20, 1). Tak więc Zmartwychwstanie Chrystusa dokonało się nocą. Nazwa Wielkanoc może więc wskazywać na porę, związaną z najważniejszym wydarzeniem dla chrześcijan.

Porównując nazwy Wielkanoc i Великдень nasuwa się pytanie, dlaczego w językach tak bliskich, mających wspólny prajęzyk, w nazwie tego samego święta pojawia się wydawałoby się przeciwstawny człon: noc - dzień. I czy rzeczywiście są to człony przeciwstawne? Na początek należy zwrócić uwagę, iż języki wschodniosłowiańskie i po części południowosłowiańskie formowały się pod wpływem kultury chrześcijaństwa wschodniego, języki zachodniosłowiańskie, w tym polski, czeski - pod wpływem chrześcijaństwa zachodniego. I to zróżnicowanie kulturowe należy uwzględnić analizując genezę obu nazw.

Doba według Starego Testamentu rozpoczynała się od zachodu słońca zgodnie ze starożytnym odliczaniem czasu: „i tak upłynął wieczór i poranek - dzień pierwszy" (Rdz. 1, 5). Taka rachuba dni zachowała się w chrześcijaństwie wschodnim. Zgodnie z nią od zachodu słońca rozpoczyna się każdy kolejny dzień cyklu liturgicznego Kościoła prawosławnego. Pierwsze nabożeństwo cyklu dobowego to nabożenstwo dziewiatej godziny (cs. девятый uac), sprawowane na pamiątkę męki i śmierci Chrystusa, która nastąpiła około godziny 9-tej (16-tej naszego czasu). Kolejne nabożeństwa, również wskazujące na porę ich celebracji to wieczernia (cs. вечерня), роwieczerze (cs. повечерие), nabożeństwo o pótnocy (cs. полунощнича), jutrznia (сs. утреня), nabożeństwo pierwszej godziny (cs. nервый час), trzeciej godziny (cs. mpeтuй час) i szóstej godziny (cs. шестой чаc) oraz zwieńczająca cały cykl Liturgia. Tak więc doba liturgiczna (czyli dzień liturgiczny, również dzień Wielkanocy) rozpoczyna się wieczorem. Zwróćmy uwagę, iż główne celebracje związane ze świętem Zmartwychwstania Pańskiego sprawowane są w Kościele prawosławnym zawsze nocą. Tuż po północy uroczystą procesją symbolizującą przyjście niewiast do pustego grobu Chrystusa, rozpoczyna się paschalna jutrznia. To właśnie podczas niej po raz pierwszy duchowni i wierni pozdrawiają się nawzajem pozdrowieniem paschalnym: „Chrystus Zmartwychwstał! „Prawdziwie Zmartwychwstał!”. Współcześnie Kościół katolicki również powraca do starożytnego obycza- 
ju sprawowania nabożeństwa Wigilii Paschalnej28 w nocy (lub przynajmniej wieczorem po zmroku). Wcześniej, od X w. ze względów bezpieczeństwa odprawiano ją w dzień w Wielką Sobotę [RE, IX, 411]. Do czuwania nocnego nawiązuje też poprzedzone procesją nabożeństwo rezurekcyjne, celebrowane w Niedzielę Wielkanocną przed świtem. Tak więc święto Zmartwychwstania Pańskiego rozpoczyna się dla chrześcijan już nocą i jest kontynuowane w dzień Niedzieli Wielkanocnej i kolejne dni wielkanocnego tygodnia.

Nazwy Wielkanoc i Великдень mogą przywodzić na myśl jeszcze jedną, choć bardzo niepewną motywację, łącząca je z kalendarzem astronomicznym (i wegetacyjnym). Należy zauważyć, iż Pascha żydowska, a w związku z nią i Pascha chrześcijańska, obchodzone są w określonym czasie cyklu słonecznego i księżycowego, związanego z wiosennym zrównaniem dnia i nocy i pierwszą wiosenną pełnią księżyca. Termin (zresztą ruchomy) świętowania Zmartwychwstania Pańskiego został wyznaczony przez sam Kościół. Ale jest nam też wiadome, iż niektóre elementy obrzędowości paschalnej zostały „zaadaptowane” z pogańskich obrzędów naszych przodków. Święto Paschy zbiegało się czasowo z ludowymi obchodami powitania wiosny, święta odradzającej się przyrody ${ }^{29}$. Nie zaprzeczają temu źródła chrześcijańskie: „W świętowaniu Wielkanocy, poza rytuałami i zwyczajami chrześcijańskimi związanymi ze zmartwychwstaniem Chrystusa, spotykane są relikty starożytnych kultur i wierzeń dotyczących powitania wiosny, świąt wegetacyjnych oraz czci zmarłych" [EK XX, 502]. W obrzędowości Paschy żydowskiej również zachowały się ślady dawnych wierzeń koczowniczych plemion nomadów, którzy wiosną, wyruszając na nowe pastwiska składali w ofierze bóstwu baranka ${ }^{30}$. Zimowo-wiosenny okres świąteczny rozpoczynający się Środa Popielcowa, a kończący obchodami tzw. Zielonych Światek nazywany jest przez polskich etnografów Świętami Dobrego Początku [Dubisz 2010, 135]. W tym czasie przyroda budziła się do życia i rozpoczynał się nowy cykl wegetacyjny. Wielkanoc stanowiła centralną część tego okresu. Po wiosennej równonocy dzień stawał się coraz dłuższy, co sprzyjało odradzaniu przyrody. Być może w dniu wiosennego zrównania dnia i nocy umownie kończyła się długa noc (a może Wielka Noc?), a zaczynał długi dzień (może Wielki Dzień?). A. Zadrożyńska w swej pracy Powtarzać czas poczat$k u$ zwraca uwagę, iż świętowanie w Polsce przebiega dwunurtowo: „Jednym z nich jest oficjalny obrządek kościoła katolickiego, czy bardziej ogólnie cykl

\footnotetext{
28 Nazwa tego nabożeństwa nawiązuje do starożytnej rachuby dni.

29 Zob. na ten temat np. Славянские древности [2004, III, 641-646].

30 Zob. np. Wstęp do Starego testamentu [1990, 166-167], por. też NECh [578-579, hasło Pascha].
} 
chrześcijańskiego świętowania, drugim - pozachrześcijańskie elementy ludowej rolniczej tradycji. Łączą się one ze sobą, tworząc uzupełniającą się całość, choć nie zawsze i nie wszędzie bezkonfliktową" [Zadrożyńska 1985, 82]. Tym cytatem chciałabym zakończyć rozważania o możliwej etymologii badanych tu nazw.

\section{Wykaz skrótów}

DAL - Даль В., Толковый словарь живого великорусского языка, 2006, совмещенная редакция изданий В. И. Даля и И. А. Бодуэна де Куртенэ в современном написании, т. 1-4, Москва.

Djacz. - Дьяченко Г., 1993, Полный черковно-славянский словарь, Репринтное воспроизведение издания 1900 г., Москва.

EK - Encyklopedia Katolicka, 1973-2014, t. I-XX, Lublin.

ESUM - Етимологічний словник украӥньскої мови, 1982-2012, голов. ред. О. С. Мельничук, т. 1-6, Київ.

Fas. - Фасмер М., 1986, Этимологический словарь русского языка, перевод с немецкого О. Н. Трубачева, т. 1-4, Москва.

IRS - Из истории русских слов: Словарь - пособие, 1993, Москва.

NECh - Nowa encyklopedia chrześcijaństwa, 2016, red. H. Witczyk, Kielce.

PBS - Польска-беларускі слоўнік, 2005, пад рэд. Г.А. Цыхуна, Мінск.

RBS - Русско-белорусский словарь, 1994, пад рэд. Я. Коласа, К. Крапівы, П. Глебкі, т. 1-3, Мінск.

RE - Religia. Encyklopedia PWN, 2001-2003, red. T. Gadacz, B. Milerski, t. I-IX, Warszawa.

SAN - Словарь иерковно-славянскаго и русскаго языка, 1847, т. 1-4, СанктПетербург.

Srez. - Срезневский И. И., 1893-1902, Материаль для словаря древнерусского языка по письменным памятникам, т. 1-2, Санкт-Петербург.

SRJ - Словарь русского языка XI-XVII вв., Москва 1975-.

SUP - Iwczenko A., Stownik ukraińsko-polski, Lublin 2003.

SS - Старославянский словарь (по рукописям X-ХI веков), 1994, под ред. Р. М. Цейтлин, Р. Вечерки и Э. Благовой, Москва.

SSJ - Словарь старославянского языка, Репринт. изд., 2006, т. 1-4, СанктПетербург.

SStp. - Stownik staropolski, 1953-2002, red. S. Urbańczyk, Kraków.

TSBM - Тлумачальны слойнік беларускай літаратурнай мовы, 2005, пад рэд. І.Л. Капылова, Мінск.

WSWO- Wielki słownik wyrazów obcych PWN, 2010, pod red. M. Bańko, Warszawa. 


\title{
Literatura
}

Basaj M., Siatkowski J., 1978, Przeglad wyrazów uważanych w literaturze naukowej za bohemizmy, cz. 15, „Studia z Filologii Polskiej i Słowiańskiej”, XVII.

Bondaruk K., 1987, Nauka o nabożeństwach prawosławnych, Białystok.

Dubisz S., Wielkanoc - Święta Dobrego Początku, „Poradnik Językowy” nr 4, 2010, s. $135-138$.

Karpluk M., 2001, Słownik staropolskiej terminologii chrześcijańskiej, Kraków.

Kwilecka I., 1996, Pochodzenie nazwy Wielkanoc w świetle historyczno-językowych badań porównawczych, [w:] Symbolae Slavisticae, SOW, Warszawa, s. $191-200$.

Moszyński L., 1973, Nazwy świat chrześcijańskich w najstarszych starocerkiewnych rękopisach ewangelijnych, Acta Universitatis Nicolai Copernici. Filologia Polska, X, Językoznawstwo, Torun, s. 105-115.

Pismo Święte, 1980, Pismo Święte Starego i Nowego Testamentu, Poznań-Warszawa.

Rygorowicz-Kuźma A., 2016, Pascha - nazwa święta żydów i chrześcijan, [w:] Chrześcijańskie dziedzictwo duchowe narodów słowiańskich, Seria III, t. 2, Białystok, s. 335-346.

Wstęp do Starego Testamentu, 1990, red. L. Stachowiak, Poznań.

Zadrożyńska A., 1985, Powtarzać czas poczatku, Warszawa.

Machek V., 1957, Etymologický slovnik jazyka českého a slovenského, Praha.

Славянские древности. Этнолингвистический словарь, 2004, под ред. Н.И. Толстого, т. 3, Москва.

Триодь постная, 1992, Издание Московской Патриархии, Москва.

Триодь иветная, 1992, Издание Московской Патриархии, Москва.

\author{
ВЕЛИКДЕНЬ OR WIELKANOC? \\ SLAVIC NAMES FOR THE FEAST OF THE RESURRECTION OF CHRIST
}

S U M M A R Y

This article focuses on the beginnings, history and contemporary function of names for the Feast of the Resurrection of Christ in Slavic languages. Particular attention is given to the Russian name Великдень and the Polish name Wielkanoc. The author conducts an in-depth comparison of both names in their linguistic and cultural aspects and attempts to find reasons for the difference in terminology. 